a WOMEN WITHOUT MEN 



\section{WOMEN \\ WITHOUT MEN}

SINGLE MOTHERS AND

FAMILY CHANGE IN THE NEW RUSSIA

JENNIFER UTRATA

CORNELL UNIVERSITY PRESS

Ithaca and London 


\section{Copyright (C) 2015 by Cornell University}

All rights reserved. Except for brief quotations in a review, this book, or parts thereof, must not be reproduced in any form without permission in writing from the publisher. For information, address Cornell University Press, Sage House, 512 East State Street, Ithaca, New York 14850.

First published 2015 by Cornell University Press First printing, Cornell Paperbacks, 2015

Printed in the United States of America

Library of Congress Cataloging-in-Publication Data

Utrata, Jennifer, 1970- author.

Women without men : single mothers and family change in the new Russia / Jennifer Utrata. — 1st Edition.

pages $\mathrm{cm}$

Includes bibliographical references and index.

ISBN 978-0-8014-5302-1 (cloth : alk. paper)-ISBN 978-0-8014-7957-1 (pbk. : alk. paper)

1. Single mothers-Russia (Federation) 2. FamiliesRussia (Federation) 3. Sex role-Russia (Federation) 4. Post-communism-Social aspects-Russia (Federation) I. Title.

HQ759.915.U87 2015

306.874'320947—dc23

2014029091

Cornell University Press strives to use environmentally responsible suppliers and materials to the fullest extent possible in the publishing of its books. Such materials include vegetable-based, low-VOC inks and acid-free papers that are recycled, totally chlorine-free, or partly composed of nonwood fibers. For further information, visit our website at www.cornellpress.cornell.edu.

$\begin{array}{lllllllllll}\text { Cloth printing } & 10 & 9 & 8 & 7 & 6 & 5 & 4 & 3 & 2 & 1\end{array}$ $\begin{array}{lllllllllll}\text { Paperback printing } & 10 & 9 & 8 & 7 & 6 & 5 & 4 & 3 & 2 & 1\end{array}$

Cover photograph courtesy of Jennifer Utrata. 
For my family 
